Trinity College

Trinity College Digital Repository

Faculty Scholarship

Spring 2016

The Sentimental Virtuoso: Collecting Feeling in Henry Mackenzie's The Man of Feeling

Barbara M. Benedict

Trinity College, barbara.benedict@trincoll.edu

Follow this and additional works at: https://digitalrepository.trincoll.edu/facpub 


\title{
The Sentimental Virtuoso: Collecting Feeling in Henry Mackenzie's The Man of Feeling
}

\author{
Barbara M. Benedict
}

\begin{abstract}
This article explains the ambiguities in Henry Mackenzie's quasiironic sentimental novel, The Man of Feeling, by examining its debt to an earlier, formative literary tradition: the seventeenth-century character collection that features the caricatured antiquarian virtuoso. Character collections, exemplified by Samuel Butler's Characters (mainly written between 1667 and 1669), constitute catalogues of ridiculed social and psychological types, prominent among whom are collector-characters derogated for antisocial self-absorption, arrogance, scopophilia, impotence, and credulity. As a sentimental novel, written in an era that highly valued sociability, The Man of Feeling reveals how this satiric inheritance complicates the praise of feeling. It reworks the structure and types of the character tradition and the figure of the antiquarian virtuoso by means of narrative frames that distance readers from the sentimental incidents; an episodic form that fractures sequential narrative; and rhetoric, themes, and characters that play on the opposition between materiality, idea, and feeling that informs the caricature of the antiquarian virtuoso. These features help to explain the ambiguity of the "man of feeling": the sentimental virtuoso who both objectifies and personalizes a world of collectible experiences.
\end{abstract}

\begin{abstract}
AUTHOR
Barbara M. Benedict holds the Charles A. Dana Chair of English at Trinity College, CT. She is the author of Framing Feeling: Sentiment and Style in English Prose Fiction, 1745-1800 (1994); Making the Modern Reader: Cultural Mediation in Early-Modern Literary Anthologies (1996); and Curiosity: A Cultural History of Early Modern Inquiry (2002).
\end{abstract}


Henry Mackenzie's sentimental novel The Man of Feeling (1771), which was read enthusiastically in its own day, has provoked ambivalent, even puzzled, responses, starting as early as the 1820 s. $^{1}$ Modern critics rightly blame this on the demise of the fashion for sensibility, particularly the book's rejection of realism, and the strains of a commercializing, imperialistic culture that severed aesthetics from politics. ${ }^{2}$ Many scholars also point to the paradoxical inadequacy of feeling and fiction to effect social action in a novel apparently advocating reform, while others note the disruptive effect of Mackenzie's irony at the expense of the putative hero, Harley. ${ }^{3}$ These responses reflect a series of problems that the book presents to latter-day readers. Among them are an ambiguous tone that wavers between satire and sentiment far more uncertainly than that of Mackenzie's model, Laurence Sterne's The Life and Opinions of Tristram Shandy, Gentleman (1759-68), and a fractured narrative form that, by alienating readers from Harley,

1 See Laura Mandell, introduction to The Castle of Otranto and The Man of Feeling (New York: Pearson Longman, 2007), xv-xxi; and Susan L. Manning, introduction to A Critical Edition of the Novels of Scottish Writer Henry Mackenzie (1745-1831), ed. Li-Ping Geng, foreword by John D. Baird (Lewiston: Edwin Mellen Press, 2011), xx-xxi. Manning also observes that contemporary readers never imagined the book offered a real "blueprint for moral-or even viable-action in the world" in her introduction to The Works of Henry Mackenzie (London: Routledge, Thoemmes Press, 1996), xiv.

2 See, for example, John Dwyer, "Enlightened Spectators and Classical Moralists: Sympathetic Relations in Eighteenth-Century Scotland," in Sociability and Society in Eighteenth-Century Scotland, ed. John Dwyer and Richard B. Sher (Edinburgh: Mercat Press, 1993), 96-118. Mackenzie deplored theatrical realism: see The Anecdotes and Egotisms of Henry Mackenzie, 1745-1831, ed. Harold William Thompson (reprint, Bristol: Thoemmes Press, 1996), 202. References are to this edition. Criticism of sentimental fiction includes, for example, Brian Vickers, introduction to The Man of Feeling, by Henry Mackenzie, ed. Vickers (Oxford: Oxford University Press, 1997), vi-xxiv; Ann Van Sant, Eighteenth-Century Sensibility and the Novel: The Senses in Social Context (Cambridge: Cambridge University Press, 1993); and Markman Ellis, The Politics of Sensibility: Race, Gender, and Commerce in the Sentimental Novel (Cambridge: Cambridge University Press, 1996).

3 See, for example, Robert Markley, "Sentimentality as Performance: Shaftesbury, Sterne, and the Theatrics of Virtue," in The New Eighteenth Century: Theory, Politics, English Literature, ed. Felicity Nussbaum and Laura Brown (New York: Methuen, 1986), 210-32, esp. 222; Barbara M. Benedict, Framing Feeling: Sentiment and Style in English Prose Fiction, 1745-1800 (New York: AMS Press, 1994), 117-26; Maureen Harkin, "Mackenzie's Man of Feeling: Embalming Sensibility," ELH 61, no. 2 (1994): 318-19, doi: http://dx.doi.org/10.1353/ elh.1994.0015; and Susan Manning, introduction to Julia de Roubigné, by Henry Mackenzie, ed. Manning (East Linton: Tuckwell, 1999), xvii. 
muddles the identification of the titular man of feeling. ${ }^{4}$ Although Harley, the apparent protagonist, appears to model benevolence, the editor and Ghostly narrator, themselves men of feeling, enact emotional withdrawal. Ildiko Csengi suggests that even Harley seems cold at times, arguing that the "man of feeling' consists in an always shifting perspective: it is an emotional lens, a technique of reading, rather than a clearly defined character type." ${ }^{5}$

Part of the reason for the historically contradictory responses to the book, then, is the difference between the ways eighteenthcentury and later audiences read literature, especially owing to the evolution and revaluation of the concept of sensibility after its heyday in the later eighteenth century. Contemporary readers' passionate responses to Samuel Richardson's Pamela, or Virtue Rewarded (1740), for example, seem anomalous to modern readers trained in irony and hardened to sentimentality. Even as sentimentalism persisted, however, irony became a common element in novels following Henry Fielding's The History of Tom Jones, A Foundling (1749). As demonstrated by sentimental novels from Tristram Shandy to Jane Austen's Sense and Sensibility (1811), eighteenthcentury readers were more comfortable than later audiences with tonal ambiguities and the mixture of satire and sentiment, laughter and tears. Tristram Shandy features the prototype of the sentimental man in Uncle Toby, whose extreme sensibility renders him both laughable and loveable, comic and tragic, material for mockery, prurience, and pity. Similarly, the prickly and neurasthenic Matthew Bramble in Tobias Smollett's Humphry Clinker (1771) serves both as comic butt and sentimental narrator. The early model of the type, Sir Roger de Coverley in Joseph Addison and Richard Steele's Spectator (1711-12, 1714), provokes laughter for his old-fashioned manners as well as sympathy for his broken heart. These sentimental characters exhibit a quirky individuality that is very different from the exemplary virtue of previous novelistic

4 Jeanne Britton argues that Mackenzie's Julia de Roubigné uses translation for a similar purpose, to disavow authorship, and also presents problems of authority and sympathy that modify Adam Smith's formulation of sympathy. Britton, "Translating Sympathy by the Letter: Henry Mackenzie, Sophie de Condorcet, and Adam Smith," Eighteenth-Century Fiction 22, no. 1 (2009): 71-98, doi: http://dx.doi.org/10.3138/ecf.22.1.71.

5 Ildiko Csengei, “I will not weep': Reading though the Tears of Henry Mackenzie's Man of Feeling," Modern Language Review 103, no. 4 (2008): 952, doi: http://dx.doi.org/10.2307/20468024. 
heroes. Nonetheless, it is worth noting, Harley lacks the marked idiosyncrasies that make such characters paradoxically admirable; if any character in Mackenzie's book exhibits this quality, it is the Ghost narrator.

In addition, the early audience inhabited a reading community that actively discussed and debated texts, since the explosion of literary material and its wide circulation made print central to both sociability and identity. ${ }^{6}$ These social practices of vigorous discussion gave texts an elasticity that facilitated contrary interpretations. Thus, the elements of deliberate irony and the tonal slither in Mackenzie's novel would not-indeed did not-prohibit it from being madly popular as, simultaneously, a treatise on feeling and material for a sceptical view of sentimental excess. Rather, it is later audiences expecting characterological complexity and interiority, as well as narrative consistency, who find this literature of transition hard to understand. ${ }^{7}$

While these historical differences in readers' expectations partially explain the difficulties presented by The Man of Feeling, I suggest in this article another, contributory cause: the specific techniques of Mackenzie's novel, which render Harley a rather odd kind of man of feeling. I will argue that the ambiguities in The Man of Feeling result partly from its adaptation of the genre of the character collection, and one of its most prevalent, specific targets: the antiquarian virtuoso. Exemplified by Samuel Butler's Characters, a group of 198 character types, mainly written between 1667 to 1669 but first published in 1759, twelve years before The Man of Feeling, these catalogues of ridiculed social and psychological types denigrate rigidity and hypocrisy, targeting collecting as an antisocial practice and collectors as impotent, credulous, self-absorbed observers. This character became freshly topical with the rise of the Royal Society and the new science at

6 See Christopher Flint, The Appearance of Print in Eighteenth-Century Fiction (Cambridge: Cambridge University Press, 2011); Andrew Piper, Dreaming in Books: The Making of the Bibliographic Imagination in the Romantic Age (Chicago: University of Chicago Press, 2009); and Naomi Tadmor, "In the even my wife read to me': Women, Reading and Household Life in the Eighteenth Century," in The Practice and Representation of Reading in England, ed. James Raven, Helen Small, and Naomi Tadmor (Cambridge: Cambridge University Press, 1996), 161-74.

7 See Michel Foucault, “Qu'est-ce qu’un auteur?”, Bulletin de la Société Française de Philosophie 63, no. 3 (1969): 64. 
the end of the seventeenth century. The Man of Feeling, however, treats collectors and collected objects ambiguously: collected things simultaneously incarnate the stereotypical rigidity of their misguided owners and denote these characters' individuality, while the collector himself is both misguided and insightful, foolish and perceptive. Correspondingly, collecting testifies both to a character's mistaken values, and to his or her sensitive response to a world animated by feeling mirrored or captured in things.

Deidre Lynch notes these tensions in sentimental fiction between vaunting people over possessions, and portraying the affective competition between objects and subjects. She observes the contradiction between characters' fungibility "in the exchange relations of 'sentimental commerce,"' and their individuation via their keepsakes in a culture of consumption; this perception revises the critical assumption that the novel is predicated on characters individualized by their interiority by suggesting that eighteenth-century readers viewed literary characters as models of how to relate to a world of things that were both individuated and mass-produced. ${ }^{8}$ This insight helps to explain much of the oddness of The Man of Feeling. However, the use of literary characters to model responses to the world of objects is not unique to sentimental fiction: it also appears in early satiric portraits of the collector, albeit rendered there without pathos. A sentimental novel born in an era sliding between satire and sentiment, in which sociability was gradually turning inward and becoming privatized, The Man of Feeling incorporates the literary inheritance of the character collection and the unsocialized collector mesmerized by objects in order to complicate its praise of feeling. ${ }^{9}$

Mackenzie's novel reworks the structure and types of the character tradition, and the antiquarian virtuoso in particular, by

8 Deidre Lynch, "Personal Effects and Sentimental Fictions," EighteenthCentury Fiction 12, nos. 2-3 (2000): 347, 355, doi: http://dx.doi.org/10.1353/ ecf.2000.0056. See also Lynch, The Economy of Character: Novels, Market Culture, and the Business of Inner Meaning (Chicago: University of Chicago Press, 1998).

9 Manning observes, "Sociability is essentially an aspect of the present in Mackenzie's prose; it is the operation of memory which takes the self back into those realms of inarticulate emotion, isolating it from others and from the continuity of sociable identity. The expression of memory is always on the point of breaking up into an emotionally powerful but socially unretrievable [sic] expression of loss" (introduction to Works, xiii). 
various means that preserve the disjunctive effect of the original character collection. These include narrative frames that distance readers from sentimental incidents; an episodic form that fractures the narrative; and rhetoric, themes, and characters that play on the tension between materiality, idea, and feeling characteristic of the collector type. ${ }^{10}$ Eighteenth-century readers understood the "thingness" of representation, the self-conscious artifices of fiction in which characters serve as both representations and literary matter. Lynch has observed, in Mackenzie's book, the interplay between two ways of conceptualizing sentimental characters: as novelistic individuals and as representations of material, written devices mirroring the typological "character," or a "readable artifact." ${ }^{11}$ As Susan L. Manning points out, Mackenzie consistently advocates sociability, and deplores the "fragmentation and loss ... characterized by failure of articulacy." ${ }^{\prime 2}$ This social dysfunctionality, be it the result of dreamy detachment, arrogance, or obsession, characterizes the antiquarian virtuoso even before it resurfaces in the sentimental virtuoso: he is so absorbed by his own feeling that he cannot communicate. In The Man of Feeling, this failure is both tragic and ridiculous, and enacts the conflict between the satirical and the non-satirical elements of the book-its depiction of rejected, impoverished, abused victims and indifferent or evil oppressors. These features help to explain the ambiguity of the concept of "the man of feeling" and of the men of feeling who appear in the novel, and inform the book's representation of an idealistic but impotent sentimental philosophy.

Character books became popular in the early and midseventeenth century after the publication of Isaac Casaubon's 1592 translation into Latin of the ancient Greek Theophrastan collection. ${ }^{13}$ One of the earliest examples, Joseph Hall's Characters of Virtues and Vices (1608), contains moral rather than professional types, such as "the Busie-Bodie," "the Profane," and "the Covetous," whose flaw lies in an irreligious worship of the material:

10 Lynch remarks on the tension between "plot and plotlessness" that results from the vignette formula of sentimental novels such as The Man of Feeling ("Personal Effects," 361).

11 Lynch, "Personal Effects," 360.

12 Manning, introduction to Works, xiii.

13 Benjamin Boyce, The Theophrastan Character in England to 1642 (Cambridge: Harvard University Press, 1947), 53. 
He is a servant to himself, yea to his servant; and doth base homage to that which should be the worst drudge. A lifelesse peece of earth is his master, yea his God, which hee shrines in his coffer, and unto which hee sacrifices his heart. Every face of his coine is a new image, which hee adores with the highest veneration; yet takes upon him to be protector of that he worshippeth ... Like a true Chymist hee turnes everie thing into silver, both what hee should eat and what hee should weare; and that hee keepes to looke on, not to use. ${ }^{14}$

Like the later greedy collector type, Hall's miser loses himself in things, confusing the transcendent with the material, God with dross, a theme pervasive in The Man of Feeling. Indeed, Hall's "Character of the Hypocrite" resembles several of Mackenzie's characters: Hall dubs him "the worst kinde of plaier, by so much as he acts the better part ... and (in the meane time) laughs within himselfe, to think how smoothly he hath couzened the beholder" (71). Like Mackenzie's hypocrites, he rends the social fabric and compromises sympathy.

The 1614 poetic collection including "many witty characters," credited to Thomas Overbury although written by several hands, also illustrates the undercurrent themes of Mackenzie's types. It too contains a description of "A Dissembler," or hypocrite, who "is an essence needing a double definition, for hee is not that hee appeares. Unto the eye hee is pleasing, unto the eare not harsh, but unto the understanding intricate, and full of windings." ${ }^{15}$ Mackenzie revisits this type when he depicts Harley deceived by a "fresh-looking elderly gentleman," leaning on a crutch to converse sympathetically in the episode entitled "His skill in physiognomy."16 Even as Mackenzie focuses on the sad fate that sympathy like Harley's meets in a corrupt society, his depiction of the card-sharper satirizes Harley's youthful credulity, for "physiognomy was one of Harley's foibles" (78). Overbury's collection also features "A Pedant," whose flaws resemble those of the virtuoso-antiquarian: he "treads in rule, and one hand

14 Joseph Hall, Characters of Virtues and Vices (London: Eleazar Edgar and Samuel Macham, 1608), 125-26.

15 A Wife Now the Widow of Sir Thomas Overburye, Being a Most Exquisite and Singular Poem of the Choice of a Wife, Whereunto Are Added Many Witty Characters, and Conceited Newes, Written by Himself and Other Learned Gentlemen His Friends (London: Lawrence Lisle, 1614), n.p.

16 Henry Mackenzie, The Man of Feeling, ed. Maureen Harkin (1771; Peterborough: Broadview Press, 2005), 77. References are to this edition. 
skans verses, and the other holds his scepter ... he never had meaning in his life, for he travelled only for words" (n.p.) and so resembles the collector in his self-absorbed accumulation of symbols in place of sociable intercourse. The Pedant also shares the collector type's sexual ambiguity: "He is a Heteroclite, for he wants the plurall number, having onely the single qualitie of words" (n.p.). Possessing both male and female characteristics, the composite, arrogant, "heteroclite" Pedant remains complete in himself. Butler's later Pedant, also preoccupied with "Words" not "Things," is similarly sexually ambiguous. ${ }^{17}$

Whereas such early collections present a series of "social, psychological, moral, and professional types," by the late seventeenth century, writers were replacing the general moral portraits invented by Theophrastes with "the historical character, a verbal portrait of an actual personage that was published singly or as an illustration within some larger context." ${ }^{18}$ Although not the first, Butler's collection of Characters exemplifies this tradition as it appears in sentimental fiction because of its blend of historical and moral aspects: Butler's characters reveal both the manners of his age, and the abstract vices and follies of men. ${ }^{19}$ Similarly, Mackenzie's types combine general qualities with details gathered from his encounters with real people. George W. Wasserman points out that Butler's portraits express his moral concern at the damage to the social fabric done by deception, be this the Virtuoso's self-delusion or the Cheat's deliberate deceit. ${ }^{20}$ This concern, too, informs Mackenzie's critique of the collector type, particularly the sentimental virtuoso.

Collecting as a literary practice became prominent in the long eighteenth century. In this period of proliferating authors and multiplying print, collecting appears as a structural technique that motivates a burst of collecting genres: encyclopaedias,

17 Samuel Butler, Characters, 1612-1680, ed. Charles W. Daves (Cleveland: Press of Case Western Reserve University, 1970), 122. References are to this edition. This collection was formed from Butler's manuscripts in the mid-eighteenth century by Robert Thyer, the Keeper of the Public Library at Manchester, and Butler apparently supplemented even this voluminous collection: seventyfour further characters appeared scattered in his work.

18 George W. Wasserman, Samuel "Hudibras" Butler (Boston: Twayne Publishers, 1976), 103. See also Daves, introduction to Characters, by Butler, 5-12; and Boyce.

19 David Nichol Smith, Characters from the Histories and Memoirs of the Seventeenth Century (Oxford: Clarendon, 1928), xxix-xxx; and Wasserman, 104.

20 Wasserman, 109-10. 
dictionaries, magazines, published commonplace books, and guidebooks to museums and sights. In addition, it becomes a technique within genres through detailed descriptions, inventorying rhetoric, and such tropes as the collection of characters whom the protagonist encounters on the road or in a stagecoach, exemplified in Fielding's Joseph Andrews (1742) and imitated in The Man of Feeling. Mackenzie joins this tradition of literary collection himself as a memoirist: his Anecdotes and Egotisms (1745-1831) contains observations, reflections on topics, and anecdotes of characters accumulated throughout his life-a sort of mental curiosity cabinet whose figures resemble those in the character tradition, and, indeed, in The Man of Feeling itself.

Notable among the anecdotes is the description of Henderson, "A College Librarian," who blends aspects of the pedant and the virtuoso:

In the College of Edinburgh about the middle or latter part of the seventeenth century there was a strange, vain, pedantic librarian, whose name, I think, was Henderson. He knew Latin well, but little of his own tongue, if that might be called English. When Oliver Cromwell was in Scotland, he visited the library of Edinburgh College, accompanied by the librarian, whom he cautioned that in the confusion of the times he must be very attentive and take care that none of the books were embezzled. After some minutes of rumination, his conductor hoped his Highness would allow him to ask if that word embezzled was derived from the Latin imbecillis. In the same spirit, a professor told me he understood that when the Professor of Mathematics of that time was shewing the librarian a comet through a telescope, Henderson said he believed that cometa was of doubtful gender. "I believe," said he, "it is hic aut haec cometa." So his pedantry, like the fine phrenzy of the poet in Shakespeare, travelled from earth to heaven.

The North Wall of the College then, as it continued to do even in my life-time, like the Tower of Pisa leaned very much outwards off the perpendicular; and there was a traditionary prediction that it was to fall on the wisest man in the College. Henderson would never pass this wall for fear of its falling on him. (Anecdotes, 34-35)

Mackenzie's portrayal of Henderson's vanity, self-absorption, Scriblerian preoccupation with obscure and dubious etymology, and sky-gazing superstition echoes Jonathan Swift's portrait of the Laputan scientists in Gulliver's Travels (1726). Mackenzie's 
description of his Italian tutor-a noble, Roman Catholic "Alchymist," critic, and "philosopher"-similarly alludes to the virtuoso tradition: a naive dreamer, this man consulted "the learned books of that occult science," and claimed to have produced "a portion of gold" by means of "a fortunate speculation," although the experiment cost him more than the gold would have had he bought it from a goldsmith (66).

The identification of collected things and collected people has etymological roots that reflect its ambiguity. The Oxford English Dictionary (OED) primarily defines "collect" as the gathering together of people: hence its liturgical meaning. ${ }^{21}$ By the late seventeenth century, however, collecting refers primarily to the process of making an assembly of objects. This shift from people gathering together to things gathered together reflects a main concern throughout the long eighteenth century about the relationships between subjects and objects, and the ways in which objects appear to be subjects, and people become things. ${ }^{22}$ Such objectification formed part of the sentimental reaction against a commercializing and mercantile society: the sentimental it-narratives at the end of the century, for example, illustrate this concern by endowing their thing-protagonists with human responses and ideas. Mackenzie's ironic rhetoric similarly expresses this same concern. Moreover, collecting also carries a highly personal charge: in the Renaissance "to collect" also meant "to recollect," "to bring oneself back to a state of composure," and, by the seventeenth century, to recall as a "conscious effort of memory." The OED also defines the word as "gathered by way of inference, inferred," the usage preferred by John Locke. These overlapping meanings reveal the historical ambiguity of collection as self-discovery and self-betrayal: an accumulation of thoughts that form the self, or of objects that hazardously replace sympathy and human feeling. This solipsism spurs satire of and sympathy for collectors as self- or thingabsorbed, attempting arrogantly or pathetically to personalize the physical world. It works in The Man of Feeling through rhetorical

21 OED Online, s.v. "collect, v.," last modified September 2015, http://www.oed .com/view/Entry/36263.

22 See Bill Brown, "Thing Theory," in Things, ed. Bill Brown (Chicago: University of Chicago Press, 2004), 1-21; Ann Bermingham and John Brewer, eds., The Consumption of Culture, 1600-1800: Image, Object, Text (London: Routledge, 1995); and Elizabeth Kowaleski-Wallace, Consuming Subjects: Women, Shopping, and Business in the Eighteenth Century (New York: Columbia University Press, 1997). 
metaphors identifying characters with the material objects of natural history.

The caricature of the virtuoso, the antiquarian or collector so obsessed by relics and rarities that he has become sexually and socially dysfunctional, had been a staple of satire since the midseventeenth century. ${ }^{23}$ Collectors were depicted as obsessive, greedy, deluded, power-crazy, sexually impotent or socially inadequate. ${ }^{24}$ Butler describes this type in his portrait of "A Virtuoso" in Characters:

nothing can raise him above the Elevation of his own Pole. He seldom converses but with Men of his own Tendency, and wheresoever he comes treats with all Men as such ... so he will talk of his Arts and Sciences to those that neither know, nor care to know any thing of them ... He is so wonderfully delighted with Rarities, and they contribute so to him, though he has shown them a thousand Times; for every new Admirer, that gapes upon them sets him a gaping too. (121-22)

Characteristically, this virtuoso suffers from lack of perspective: he stares into things and sees himself reflected.

The Virtuoso's "Ignorance of himself and his Undertakings" (122) leads to his peculiar mixture of self-deluding imagination and entrancement with objects. This quality also characterizes the collector of things from the past, the "Antiquarian" who

is one that has his Being in this Age, but his Life and Conversation is in the Days of old. He despises the present Age as an Innovation, and slights the future; but has a great value for that, which is past and gone ... He throws away his Time in enquiring after that which is past and gone so many Ages since ... His Days were spent and gone long before he came into the World, and since his only Business is to collect what he can out of the Ruins of them. (76-77)

This obsession foreshadows the proto-Romantic sentiment des ruins. Treated sympathetically rather than satirically, the love of

23 See Walter E. Houghton, "The English Virtuoso in the Seventeenth Century," Journal of the History of Ideas 3, no. 1 (1942): 51-73, 190-219; and Craig Ashley Hanson, The English Virtuoso: Art, Medicine, and Antiquarianism in the Age of Empiricism (Chicago: University of Chicago Press, 2009), 13-14, $18-19$.

24 See Benedict, Curiosity: A History of Early Modern Inquiry (Chicago: University of Chicago Press, 2001), 25-70. 
ruins that finds transcendence in decay marks many sentimental characters. Uncle Toby in Tristram Shandy, for example, naive, self-absorbed, boorish, and oddly childish, works to criticize the heartless, forgetful, and materialistic present even while being teased for delusion..$^{25}$ Nonetheless, such characters often appear impotent and defanged, looking and reacting rather than doing and acting. Their nostalgia results in absence from the present: the antiquarian dwells in his mind, not in society, and accumulates fragments and ruins instead of treasure. ${ }^{26}$

While such men of feeling as Uncle Toby share characteristics of the virtuoso type, they also display differences that show how sentimental authors revise the despised trait of otherworldliness in antiquarian collectors into spiritual sensitivity, a closeness not to the past of civilization but to their own past as innocent children. Mackenzie depicts this sentimental virtuoso type not only in Harley, but also in the nostalgic narrator of The Man of Feeling. Unlike Butler's Virtuoso, who "slights any Thing that is plain and easy ... and bends his Forces against the hardest and most improbable," Mackenzie's narrator-of-feeling, the Ghost, enjoys simple and childish pursuits (122). At the same time, the sentimental hero's characteristic skill of finding treasures in trash-Harley's recognition of the saint in the prostitute, like Miss Atkins, and honesty in the dishonest-constitutes an evolution of the virtuoso's antisocial valuations: he ignores what the world values, like wealth and fame, to prefer what it discards, personalizing things into souvenirs. Whereas Butler's Virtuoso longs for fame-he cares not "whether he be applauded by an Ass, or a wiser Creature, so he be but applauded" - the sentimental man never seeks or earns applause (124). At the same time, both kinds of virtuoso exhibit a naive misevaluation of the social hierarchy parallel to their misevaluation of objects. The trademark detachment from worldly judgments is stamped on both.

25 See G.A. Starr, "Sentimental Novels of the Later Eighteenth Century," in The Columbia History of the English Novel, ed. John Richetti (New York: Columbia University Press, 1994), 181-82.

26 See Thomas McFarland, Romanticism and the Forms of Ruin: Wordsworth, Coleridge, and Modalities of Fragmentation (Princeton: Princeton University Press, 1981), 13-45; Harkin, introduction to The Man of Feeling, 15n1; and Christopher Woodward, In Ruins: A Journey through History, Art, and Literature (London: Chatto and Windus, 2001), 2. 
The Man of Feeling, like other sentimental fictions, reworks through metafictional devices the opposition between the material and the conceptual that prompts satires of the virtuoso and antiquarian. These devices play on the tensions between the materiality of text and humanity, and their imaginative comprehension, and between the decontextualized episode or collectible, and the narrative or collection. The first example is the conceit of the found manuscript. Like novels from Daniel Defoe's Moll Flanders (1722) to Ann Radcliffe's The Italian (1797), The Man of Feeling includes an editorial frame that positions the main story as an authentic manuscript, discovered by chance and presented by a disinterested editor. The foremost purpose of this device is to facilitate the reader's suspension of disbelief and therefore sympathetic identification with the hero by denying the artificiality, or artfulness, of the story since a found manuscript purportedly has no literary pretensions. Further, by acknowledging the physicality of the actual text, the author presents the story as both more and less real: more real, in that it is a material object, and less real precisely because it merely represents, literally re-presents, an unverified tale. The convention of the found manuscript casts the story as a thing: a physical object encountered in the material world. As Susan Stewart observes, "representation implies a type of substitution that undermines its own status as a purportedly transcendental gesture, figuring a referent that always exceeds and escapes the very aim of representation's function-a sufficient signification," since "the sufficiency of representation, its authority and its capacity for attribution and comprehension, will depend upon a necessary forgetting." ${ }^{27}$ Likewise, novel readers have wilfully to forget they are reading a writer's representation rather than an "authentic" document. Mackenzie confronts this paradox with multiple frames that repeatedly underscore the unreliability of the document and the ambiguity of its authorship. The effect of this device is to make the text appear as a "ruined" artifact, and so to authorize the editorial arrangement of collecting the textual evidence-the episodes and sentiments-to make a whole.

Mackenzie emphasizes the thingness of this scriptural object by Sterne-like typographical tricks: asterisks and editorial insertions,

27 Susan Stewart, Crimes of Writing: Problems in the Containment of Representation (New York: Oxford University Press, 1991), 6. 
such as "[Here a considerable part is wanting.]", that remind the reader of the text's ambiguous status as an incomplete bundle of narrative data (76). Of course, this device is transparent: readers well know that only the author could be aware that a "considerable" part is missing, since only the author would know he had written-or not written-much more than is left. For example, after the editor's introductory account of finding the manuscript, the novel proper begins with chapter 11 , marked by a footnote declaring, "The Reader will remember, that the Editor is accountable only for scattered chapters, and fragments of chapters; the curate must answer for the rest. The number at the top, when the chapter was entire, he has given as it originally stood, with the title which its author had affixed to it" (50). This rhetoric echoes that of a Scriblerian editor, or a natural philosopher scrupulously recording his encounter with the object or datum retrieved for his collection: he steps back from a conclusion about the overall shape of the narrative, class, or species in order to give close attention to its particularities. At the same time, it nudges the "Reader" to supplement the text by imagining the missing parts. The persistent pointing to the text's materiality demonstrates what Stewart calls the "crisis in authenticity arising from various phenomena characterized by simulacral and nostalgic themes and forms" in the eighteenth century. ${ }^{28}$

Although The Man of Feeling apparently advocates sentimental philosophy, it repeatedly frustrates attempts to make it coherent or moral: the contradictions between its didactic function and the scenes of indiscriminate feeling undermine both. ${ }^{29}$ Digressionsespecially the long, sad story of Old Edwards-and Harley's shifts from teary nostalgia to lust and compassion fracture the narrative, and highlight the tension between the integrity of each incident and the shape of the entire tale. Onto the basic plot of Harley's journey to London to improve his fortunes by leasing some lands owned by the government, Mackenzie hangs a fretwork of incidents illustrating duplicity and feeling. Mackenzie confessed that The Man of Feeling is "different from most others [novels] as containing little plot or incident but merely a sketch

28 Stewart, Crimes of Writing, 5.

29 Janet Todd points out that the political implications of injustice are undermined by the emphasis on sentimental response. Todd, Sensibility: An Introduction (London: Methuen, 1986), 3-4, 88-89, 98-99. 
of some particulars of the life and sentiments of a man of more than usual sensibility" (Anecdotes, 186). ${ }^{30}$ While Harley and the narrating Ghost bind the book together, Mackenzie's structure obeys the formula of sentimental fiction by presenting a series of dissociated and fragmented episodes that evade progressive narrative. ${ }^{31}$ Indecipherable (or incomprehensible) writing, an incoherent structure, and the lack of moral argument typically mark the cataloguing, inventorying, Scriblerian style of the virtuoso mocked in Restoration and early eighteenth-century satire. Their appearance here to describe the ghostly narrator underscores the connection between the collection of physical objects and the sentimental collection of anecdote and episode: between material and mental collection, and the transformation of the understanding of the past from a physical to an imaginative enterprise.

Despite this structure and the thingness of the text, the book itself vaunts sentiment: the sympathetic responses that characterize natural virtue. If the book appears as an object, fractured but collected by the editor, the ultimate act of making sense of the fragments rests with the reader. It is her or his task to put together the separate elements into a meaningful whole-to make a moral narrative-by identifying what elements the incidents in the book share. ${ }^{32}$ Mackenzie indicates this responsibility by the ironic introduction in which the nameless editor recounts his discovery of the script. After failing to find game to shoot on a hunting expedition with his friend, a curate, the editor learns that the gun-wadding used by his companion consists of the remains of a shredded manuscript relating Harley's history. The curate recalls that a mysterious, solemn, old gentleman dubbed "The Ghost" by the villagers had left the bundle of papers in his lodgings in the parish. This spectral author functions as literally the spirit behind the words, the animating principle linking the events and

30 The book's episodes resemble separate items in a collection of souvenirs. Stewart identifies the decontextualization of objects within collections and the emotional displacement that souvenirs represent in On Longing: Narratives of the Miniature, the Gigantic, the Souvenir, the Collection (Baltimore: Johns Hopkins University Press, 1984), especially 132-54.

31 See Todd, 6; McFarland, 13-45; and Harkin, introduction to The Man of Feeling, 15n1.

32 Ellis observes that Mackenzie thought "that the novel's use of narrative made it an unusually forceful genre" in persuading readers to benevolence (16-17). 
disparate tones of the episodes in the story. The curate, however, though the representative of secular spirituality, remains dully insensible to the charms of feeling, as he confesses, "I began to read them, but I soon grew weary of the task; for, besides that the hand is intolerably bad, I could never find the author in one strain for two chapters together: and I don't believe there's a single syllogism from beginning to end" (48). Mackenzie's reader, in contrast, should act as the spectator of a collection, who observes and records each individual element, locates the root similarities, and finally puts them together to explain how the evidence-the data-fits into a whole. Mackenzie underscores the significance of this act when the editor reveals that he is carrying "an edition of one of the German Illustrissimi, for the very same purpose" of gun-wadding, while admitting that upon reading Harley's history he "was a good deal affected" by the "bundle of little episodes," responding as he had to the works of the famous sentimental authors Samuel Richardson and JeanFrançois Marmontel (48-49). The continental philosophers, religious preacher, and sentimental novelist all share the project of mapping human and physical nature. The editor, although he does not revise the "medley" into a complete narrative, points the way to understanding its evidence by and as sentiment (48).

Mackenzie's rhetoric also underlines the complex relationship between materiality and imagination. The materials and processes of natural philosophy serve in the novel as metaphors for the process of identifying and internally assembling human types, and thus of understanding humanity. Both Harley and the nameless narrator acquire this knowledge through some form of travel, which enables them to collect contemporary species. In the opening chapter, the narrator, deploring the "rust" that accumulates on the rural British, accepts the advice of his friend, Ben Silton, to "rub it off by travel" (50). The narrator objects: "Why, it is true,' said I, 'that will go far; but then it will often happen, that in the velocity of a modern tour, and amidst the materials through which it is commonly made, the friction is so violent, that not only the rust, but the metal too is lost in the progress"' (51). This metaphor is far from original: indeed, one of the "Brief Panegyrickes to the Authors Praise" in Overbury's character collection, addressed not to the author but "To the Booke," asserts, "Hid medals rust, which 
being used grow bright."33 In Mackenzie's work, the resemblance between material and moral is more ambiguous: by straining the metaphor of rust, the narrator contrasts tough material reality with sensitive humanity. Silton's retort defends his own "encrustation" as "wisdom," whereupon the narrator replies, "You are right ... and sometimes, like certain precious fossils, there may be hid under it gems of the purest brilliancy" (51). This discourse represents humans as not only things in themselves, but also collections of things: cabinets of fossils and jewels. It participates in the mercenary project of the acquisitive, corrupt society. At the same time, it points to the illumination that sentimental heroes' uniqueness can offer: as human-things, they resemble both frozen remnants and eternal treasures, whose very stasis preserves their value. Silton shows that one may find the perspective and wisdom purportedly offered by the Grand Tour within the self, immured in quotidian, domestic reality.

These tensions within the narrative mirror the tension between the book as a thing and the book as an ideational experience. For example, although Harley cannot define the "кa入ov, or beautiful," nonetheless "a blush, a phrase of affability to an inferior, a tear at a moving tale, were to him, like the Cestus of Cytherea" (55-56). The equation between the act or experience that constitutes beauty for Harley and Venus's precious girdle replays the clash between experience and thing. Similarly, when Silton identifies two species of "bashfulness" - stupidity and sensitivity - the narrator identifies Harley as "the latter species of bashful animals," devolved from an ancient family to the near-poverty of $£ 250$ a year (51). By labelling the extraordinary Harley as an "animal," this rhetoric betrays the inadequacy of natural philosophy to grasp the heart of a man.

While the editor serves as one kind of collector-of the book's fragile materiality - the narrator, "a grave, oddish kind of man," serves as another (48). A misanthrope, "known by the slouch in his gait, and the length of his stride," he avoids socializing, unless with innocent children on, ominously, "the great stone at the door of our church-yard," and walks "a-nights" in solitary contemplation (48). He resembles Butler's "Melancholy Man," "one, that keeps the worst Company in the World, that is, his own; and tho' he be always falling out and quarrelling with himself, yet

33 G.R., "To the Booke," in A Wife, n.p. 
he has not power to endure any other Conversation. His Head is haunted, like a House, with evil Spirits and Apparitions ... His Sleeps and his Wakings are so much the same" (96-97). Like an antiquarian virtuoso, this narrator finds more meaning in the past than the present, in dreams than in life. He embodies memory: called "The Ghost," half already in death, his strangely corporeal presence haunts the countryside as a living reminder of Harley's fate. He dwells in his collection, although he has collected the past-Harley's experiences-rather than things or words. In his first paragraph, he notes that Britons' rusticity "often goes with a man to his grave; nay, he dares not even pen a hic jacet to speak out for him after his death," and then beseeches the reader, "Let me paint the honest old man: 'tis but one passing sentence to preserve his image in my mind ... He is now forgotten and gone!" (50). Just as the Ghost's physical ungainliness signifies his asocial and anti-sexual nature, so his preoccupation with loss, memory, and death mark his detachment from the material world. He himself serves as a memento, a reminder of life's fragility and death's omnipotence.

Both the virtuoso and the antiquarian obsess about material objects, often relics, at the cost of sociability, and both draw satire for their confusion of the physical and the conceptual. The seventeenth-century caricatures of the Antiquary and the Virtuoso that populate satires by Aphra Behn, William King, Ned Ward, and many others ridicule their attempt to find transcendence through material objects. Depicted as self-centred, lost in classificatory ambiguities and an endless enterprise of accumulation, the Antiquary, in particular, pursues time in things, and, "conflated with the objects of his study," supplies "myriad jokes about rust and dust, death and decay." ${ }^{34}$ This confusion of self and thing characterizes Harley as a body of feelings often at war with his judgment, and further echoes the confusion of the idea of the novel with its tattered, ruined manuscript. As James D. Lilley notes, "The sentimental flâneur ... is ruined feeling," constantly "observing ... decay," and is thus parallel to the objectprotagonists in it-narratives. ${ }^{35}$ Just as the Antiquary and Collector

\section{Hanson, 140.}

35 James D. Lilley, "Henry Mackenzie's Ruined Feelings: Romance, Race, and the Afterlife of Sentimental Exchange," New Literary History 38, no. 4 (2007): 654, http://www.jstor.org/stable/20058032. 
types reveal the dangers presented by a practice of collecting that subordinates cultural significance to the collector's whim, and appears to vaunt the material over the conceptual, so Harley's self-absorbing feeling compromises sympathy, and risks turning him into a rusted ruin himself. At the same time, his alienation from the world opens for the reader a freeing perspective that renders the ordinary extraordinary.

The virtuoso's idiosyncratic valuations, symbolized by antiquarianism and the fetishization of curiosities, conventionally result in his sexual as well as social inadequacy, but Mackenzie revises this trope to endorse individual resistance to social corruption. In the earlier farce Three Hours after Marriage (1717), Alexander Pope depicts these flaws in the prototypical Dr Fossile, whose very name denotes his obsession with the dead past. He stuffs his cabinet of curiosities with the typical exotica of museums: a crocodile, a mummy, a "flying Dragon" deemed "cheap" at fifteen guineas, an expensive butterfly and spider-the acquisition of these curiosities eats up his fortune and the objects serve to defraud him by concealing his wife's lovers. ${ }^{36}$ The sentimental virtuosi in The Man of Feeling betray similar traits, but to different ends. Lilley argues that Mackenzie's book uses the trope of the ruin to undermine normative heterosexual desire, and to inscribe a nostalgic longing for the "private differences" that enlightenment philosophy denies. He points out the contradiction between feeling "as a principle of public exchange" and as "a totally private essence" since "the ideology of ruin ... obscures private feeling and enables these democratic political values to be publicized and exchanged" (650). While Harley's isolated sensibility in a world of hypocrites and manipulators works to reproach social corruption, it thus also reworks the seventeenth-century satirical charges against collectors for preferring objects to people, for sexual ambiguity or impotence, for antisociality, and for opposing social valuations by accumulating and studying objects society deems rubbish.

The collector type's supposed perversion of value is often represented as the loss of identity symbolized by physical decay. Butler's three versions of this type, "The Antiquary," "A Curious Man," and "A Virtuoso," are all marked by the invasion of the

36 Alexander Pope, John Gay, and John Arbuthnot, Three Hours after Marriage (London: Bernard Lintot, 1717), act 3, line 56. 
body. ${ }^{37}$ The Antiquary, for example, "has so strange a natural Affection to worm-eaten Speculation, that it is apparent he has a Worm in his Skull" (94). Like his body, his identity is configured by his collection: "He honours his Forefathers and Foremothers, but condemns his Parents as too modern, and no better than Upstarts. He neglects himself, because he was born in his own Time ... He spends one half of his Time in collecting old insignificant Trifles, and the other in shewing them, which he takes singular Delight in; because the oftener he does it, the further they are from being new to him" (94-95). By revising his heritage and circulating himself with his "Trifles" as a showpiece for others, the Antiquary makes himself an object within his collection. John Earle's earlier portrait of the Antiquary in his Micro-cosmographie, or A Piece of the World Discovered; in Essayes and Characters (ca. 1628) similarly employs somatic imagery to turn the Antiquary inside out: "He is a man strangely thrifty of Time past, and an enemy indeed to his Maw, whence he fetches out many things ... now all rotten and stinking." ${ }^{38}$ Rather than absorbing, the Antiquary's body expels: it makes meaning into waste objects, reducing history to mere material. In her "Character of a Pedant," Mary Astell also eviscerates the antiquarian body, but in reverse: her antiquarian loses the material in the conceptual, since, "by their retir'd and unactive Life, their neglect of Business, and constant Conversation with Antiquity, they are such Strangers to ... the Domestick Affairs and Manners of their own Country and Times, that they appear like the Ghosts of Old Romans." 39 The Antiquary becomes what he studies. Astell's Pedant's body vanishes into imagination; he lives death. Butler's Antiquarian becomes wholly material as his very body becomes a collectible: he "had rather not be than not appear" (188). ${ }^{40}$ As Antiquaries subject the present to the past in

37 Butler, 94, 150, 185. See also Daves, introduction to Characters, by Butler, xii. Houghton observes that Shadwell's Virtuoso is a type of antiquary in "The English Virtuoso" (73).

38 John Earle, Micro-cosmosgraphie, or A Peece of the World Discovered in Essayes and Characters (London: William Stansby for Edward Blount, 1628), no. 9, n.p.

39 [Mary Astell], An Essay in Defence of the Female Sex, Written by a Lady, 2nd ed. (London: A. Roper, 1696), 27.

40 See also "A Curious Man," whose "perpetual Dotage upon Curiosities at length renders him one of them" (150). 
their futile attempt to collect time, collectors lose meaning for love of the detail. The collecting character is emptiness dressed in detail: a somatic catalogue in which imagination usurps physical identity, the material body. ${ }^{41}$

Harley himself combines several Butlerian characteristics, deemed virtues in the sentimental context yet traditionally derided. Most important is credulity, the virtuoso's trademark folly, which Butler depicts in "A Credulous Man":

$[\mathrm{He}]$ has a gentle, easy, complacent belief, and will not deny any man the civility of his faith to any thing, especially if it be false; otherwise it is no courtesy, for if it be true every man ought to believe it ... $\mathrm{He}$ is the same thing to a lyar, as a thief is to a receiver; what one comes dishonestly by, the other entertains and disposes of, and in that appears to be the worse of the two; for if it were not for easy believers, liars would be at a loss, and either leave that vanity, or use it to no purpose. Every man's word is canonical with him, and he never questions the authority of it, but believes as the church-porch believes. He is very free of his faith, because he comes easily by it; for it costs him no consideration at all, and he is sure he can hardly part with it for less than it is worth. He esteems it generous to be persuaded freely, and not to stand with any man for such a trifle as a lye is ... He has a worse opinion of himself than the rest of the world; for he cannot believe any man will lie and forswear himself, though he has done it himself never so often. He finds most delight in believing strange things, and the stranger they are, the easier they pass with him; but never regards those that are plain and feasible, for every man can believe such. (264-65)

Harley similarly credits every person he meets with telling the truth, from the card-sharping footman to the hypocritical benevolist, and although occasionally his character-reading is correct, as in the case of Miss Atkins, most of the time he is fooled. Just as Butler condemns credulity for its social effects, so Harley's sympathetic egalitarianism works in Mackenzie's novel to encourage deception.

Harley also suffers from a form of the virtuoso's deplored scopophilia peculiar to the sentimental hero, whose very sentiment demonstrates the futility of one person's responses in a mercenary world: like the virtuoso, he prefers looking to acting, collecting to

41 See Hanson, 142. 
performing. When he deliberates over whether to give a charitable donation to a beggar, the shilling slips from his hand. He does not consciously decide to indulge compassion over the "Virtue" that "held back his arm," but his body acts for him: "His fingers lost their compression" over the coin, and it falls on the ground, to be snatched up by the beggar's dog (61). It is as if Harley can only watch his own body in action. Harley's scopic curiosity extends even to gaping at the mad. The narrator remarks that, "of those things called Sights in London, which every stranger is supposed desirous to see, Bedlam is one," and although Harley objects to the inhumanity, he visits the hospital anyway (66). In his courtship of Miss Walton, Harley's love of looking disastrously replaces acting, as he only declares his love for her moments before dying.

Harley's sensibility also works in the novel as a mechanism for the self-injurious collecting of sentiment, particularly within Bedlam, where mad types abound, "making explicit the connection between the virtues of sentimentality and obsession and the dangers of insanity." ${ }^{42}$ The stereotypical Bedlamites-the Newtonian astrologer-natural philosopher maddened by star-gazing, the ruined merchant, the Bentley-obsessed pedant, the Chan of Tartary, and the lovelorn maiden-themselves constitute a curiosity cabinet. ${ }^{43}$ Harley himself collects extemporaneous poetry inscribed on windows and glasses, mirroring the enterprise of recording ephemeral literary culture of such antiquarians as Edward Harley, second earl of Oxford, and Thomas Percy (101). This activity demonstrates Harley's ability to perceive the valuable in what others deem worthless: he preserves what they discard. At the same time, it dramatizes a collecting impulse that seeks to immortalize the transient and to personalize the external world.

Just as Harley's tour of London mirrors the Grand Tour, his accumulation of experiences resembles a collection of souvenirs: the narrator remarks that, when Harley returns from his tour, "his enjoyment was as great as if he had arrived from the tour of Europe, with a Swiss valet for his companion, and half a dozen

42 Lennard J. Davis, Obsession: A History (Chicago: University of Chicago Press, 2008), 53.

43 William Hogarth illustrates the classic types of mad people-the tailor, the philosopher, the distraught lover-in A Rake's Progress, plate 8. See also Michel Foucault, Madness and Civilization: A History of Insanity in the Age of Reason, trans. Richard Howard (1967; reprint, London: Routledge, 1989), 111-50. 
snuff-boxes, with invisible hinges, in his pocket" (116). Again, however, Harley's collection also proves his moral probity, since, although he quantifies and objectifies his experiences, he rates them above objects. Harley also exhibits a sentimentalized version of the virtuoso's solipsistic fascination with the new in his credulous curiosity about the people he encounters, each of which represents a fresh example of humanity. Like the virtuoso, he seems not to learn how to generalize from his experience; rather, he remains fascinated by the individual samples, a trait that marks both his humanism and his scientism. Like quack virtuosi who boast of astrological prowess, he thinks "of turning fortune-teller for a week or two," despite his knowledge of the fraudulence of the practice, in order to collect more human types (60). Once again, he does not act on his plan, and, ironically, his inaction preserves his integrity.

Collecting is often-or often perceived as-mesmerizing and obsessive: "thinking about one thing too much," which leads to the inability to act. ${ }^{44}$ Caricatures of collecting types depict them as dazzled by possessions that replace people, and render the collectors socially impotent. In The Man of Feeling, this translates as proto-Romantic brooding, which constitutes one of the problems of all three of the most prominent men of feeling in the novel. The nameless editor loses his "point" and misses his game as the novel opens; the Ghost secedes from social action; Harley shrinks from the Grand Tour, and hesitates fatally long to sue for his fortune or his bride (47). What preoccupies all three is the conviction that "all is vanity and vexation of spirit," a "nauseated listlessness" that arises from the failure of the world to match their ideal (47). Importantly, none of these characters obsesses over things, and their perception of the world's inadequacy results from their own sensitivity; nonetheless, they remain locked in their own private perceptions, as detached from the world as the collector.

In addition to the editor, the Ghost, and Harley, briefly sketched sentimental virtuosi who share the traits of caricatured natural philosophers also appear in The Man of Feeling. They populate several of the episodes: Harley's sanctimonious old aunt; Miss Atkins; the fraudulent, boasting young "gentleman" ex-footman and gauger; the characters in the stagecoach; and so forth. Like 44 Davis, 61. 
Butler's characters "A Philosopher," "A Melancholy Man," and "An Hypocrite," they represent social types, but they also work to dramatize Harley's sensibility. Mackenzie's Misanthropist especially, like the crusty, Matthew Bramble-like unnamed narrator, exhibits an obsessive preoccupation with vices and collected truisms, and an inward-turning, antisocial philosophy characteristic of a Butlerian "Philosopher," who "Seats himself as Spectator and Critic on the great Theater of the World, and gives Sentence on the Plots, Language, and Action of whatsoever he sees represented according to his own fancy" (94). Mackenzie's Misanthropist complacently discovers in all men and experience a reiteration of his conviction that "man is an animal equally selfish and vain" (76) ${ }^{45} \mathrm{He}$ also resembles a version of Butler's type "The Self Conceited or Singular," whose obsessive self-love devolves into antisocial vanity:

$[\mathrm{He}]$ is a separatist from the rest of mankind, that finds nobody fit for him to comply with but his own dearly beloved self ... He likes no man's humour, judgment, or opinion but his own, nor that as soon as he finds any man else concur with him ... He sets a high value on the meanest trifle that comes from himself, as a lover does on any toy he receives from his mistress; but disesteems any thing else how good soever, because it is not his. All his parts are curiosities, and he values them the more as the owners of rarities use to do, because he believes nobody has them but himself. (309-10)

The Misanthropist exhibits this self-love in his "triumphant contempt" as he compares Harley's new coat to his own, and sees in it "the sleekness of folly, and the threadbareness of wisdom" (74). Like the Antiquarian, Curious Man, and Virtuoso, he illustrates self-absorption and vanity.

Among Mackenzie's characters in his Anecdotes and Egotisms are several that reflect classical types in the character tradition and resemble figures in The Man of Feeling. The miser, for example, also appears in Butler's Characters, and shares the collector type's solipsism and antisociality. Butler writes,

45 Mackenzie confessed that "the brother of the misanthrope in The Man of Feeling found that he could never be rich but he might be very happy. That character and his disgust with his profession nearly my own case" (Anecdotes, 190). 
The Miser Is like the Sea, that is said to be richer than the Land, but is not able to make any Use of it at all, and only keeps it from those that know how to enjoy it if they had it ... He gathers Wealth to no Purpose but to satisfy his Avarice, that has no End ... All that he has gotten together with perpetual Pains and Industry is not Wealth, but a Collection which he intends to keep by him more for his own Diversion than any other Use ... He makes no Conscience of any Thing but parting with his Money, which is no better than a Separation of Soul and Body to him ... His Riches are like a Dunghill, that renders the Ground unprofitable that it lies upon, and is good for nothing, until it be spread and scattered abroad. (195-97)

Although Mackenzie's version eschews specific reference to collecting, it reiterates the trope of money preferred to life, and the association of lucre with death. After describing several "Misers" of whom he had heard, he concludes:

In misers there is a sort of unwillingness to bequeath money to any but their heir, with whom they very oddly seem to identify themselves. I knew a lady of this disposition who, having made her will leaving several legacies, when she heard of the death of any of her legatees came to a friend of hers who told me this anecdote, in great joy exclaiming "Such a person is dead; there is a lapsed legacy!"- She did not think of altering her will or scoring through the name of any legatee, but thanked Heaven for saving her that trouble by the death of the person. (64)

Like Butler, Mackenzie targets the antisocial aspect of miserliness: its flaw is moral, the preference for self over others.

The flaw of antisocial self-preference, typical of the virtuoso and antiquarian, characterizes most of the derided characters in The Man of Feeling, from the "philosopher" to the "beggar." However, these characters also illustrate another running theme associated with collectors of material things: the replacement or enhancement of a real self with an imagined or invented identity. This is both antisocial and iconoclastic, a resistance to a normative identity that simultaneously threatens and triumphantly contradicts public judgments. Both the beggar in The Man of Feeling and the Beggars in Anecdotes and Egotisms appear as con men and frauds, working on the sympathy of others to enrich themselves, but at the same time they illustrate the general human tendency to forge an individual identity in the face of 
public definitions of the self. This may occur when you pretend to be something other than you are to gain sympathy, attention, or profit, or when you fail to recognize or accept what you are out of vanity, obstinacy, or idealism. The footless man who enlists as a "stout soldier," for example, misrepresents himself from a refusal to accept the public sense of his selfhood as disabled; ironically, the female who mimics epilepsy does the opposite by redefining herself as sick. Both nonetheless adhere to a self-definition that flies in the face of the apparent. To highlight the irony of this resistant sense of self, Mackenzie includes the startling honesty of thieves who openly admit their self-interested values. In The Man of Feeling, the beggar who attempts to bamboozle Harley into telling his fortune ultimately admits that, after losing his employment, he lost the desire to work and prefers to live by deceit, and Mackenzie revisits this theme in Anecdotes and Egotisms under "Thefts." Here, Mackenzie describes shoplifters and pilferers, one of whom, being brought before a judge, defended himself by declaring "that he was born with this propensity and had just got a habit of stealing-'Well, Sir', replied the judge, 'and we have a habit of hanging such persons"' (69). Mackenzie thus revises the character tradition's indictment of the delusions and self-centeredness of the collector type into a more complex illustration of human imagination.

Much of the tonal confusion in The Man of Feeling between sympathy for and mockery of the man of feeling thus results from Mackenzie's incorporation of the character tradition. This literary strategy reflects the shifting of contemporary tastes, habits, and genres, from satire to irony, from socialized to private reading, and from theatre to prose fiction. These shifts enable a conflation of incongruous literary techniques, epitomized by the transformation of the caricatured collector as it moves between representing a derogated social misfit to incarnating integrity in a heartless world. The figure continues to crop up in characters like Jane Austen's General Tilney in Northanger Abbey (1818), Charles Dickens's Quilp in The Old Curiosity Shop (1841), and John Fowles's Clegg in The Collector (1963). However, in the period when the tradition of satire was eroding in the face of sentimentalism, the satirized collector became a more complex figure, and in Mackenzie's rendition, a more ambiguous one. Harley's, the 
narrator's, and the Ghost's combination of sensitivity and rigidity reveals a tension between static types and realized individuals. While this tension expresses literature's perpetual double aim of rendering the unique identifiable, of depicting individuals who yet are recognizable products of their society, at the same time, it shows in Mackenzie's novel an awareness of the artificiality of representation peculiar to this historical period. This may help to account for the dip in the novel's popularity as sentimentalism becomes the staple stuff of fiction, and the collecting character grows from a satiric caricature to a sensitive victim, attempting to shore up feeling, memory, and love in a cold world.

Mackenzie's The Man of Feeling exemplifies the importation and transformation of the structure, themes, and characters of collecting and the collector type into sentimental narrative. This heritage informs the novel's philosophical incoherence in marrying a social critique and advocacy of emotion to a demonstration of the futility of such emotion as social action. It does so by deploying the traces of the traditional satire of excessive sentiment, especially the love of things and the worship of the past. At the same time, the main sentimental virtuosi in the book exhibit their need to personalize the world by collecting experiences valued as highly as gems or antiquities. Still, excessive sentiment resembles materialism as a form of self-absorption that endangers sympathetic sociability, and characterizes the derogated collector type. By the structural devices of framing, an episodic form that constitutes a collection of scenes, dramatized feelings, and character sketches, and by the rhetoric of materiality, Mackenzie reworks the earlier tropes to present a new version of the conventional figure of a man so obsessed with the past and himself that he cannot function socially, act decisively, or woo successfully: the sentimental virtuoso.

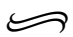

